\title{
A Free-Spirited Dream
}

\section{Chamille Weddington}

My eyes see

A Free Spirit dream

Of things wished for, things imagined

And things that come true

Faces friendly, though unknown

The rush of newness, the experience of free

The anticipation of the unexpected

Lighthearted just to be

Some in color others in black and white

Creativity touching my mind

Free-spirited smiles that leave the trite behind

Pieces of them visit me during the day

They give me a rush

Give me a peek - in them I see a friendlier way

Stay dreams

Stay - I'll grab you in-between my day, grab your ends,

Like fingers holding braids

That threaten to fray

Tease at me, and then fly away.

C. Weddington $(\bowtie)$

Columbia College Chicago, Chicago, IL, USA

(C) The Author(s) 2018

M. Duster et al. (eds.), Michelle Obama's Impact

on African American Women and Girls,

https://doi.org/10.1007/978-3-319-92468-7_25 